\title{
Hepatic Portal Vein Gas
}

はじめに

肝門脈内ガス（以下HPVG）は非常に稀れな教候で， 英米の文献で70例，本邦では自験例を含めて 2 例の報告 しかみられない，成書にも)HPVG の記載はなく，本症 の知織が無ければ，まず見落とされると言つてよい，し か子本症の原疾患の大部分は激症の経過を辿り，数日以 内に死亡するため，䒖速な診断と積極的な治療が必要で ある. 血管内ガス発生機序は敗血症に起因すると考えら れるが，不明な点る多い，最近，吾々は大腸菌が起因 菌と思われる汎発性腹膜炎で死亡した重症糖尿病患者に HPVG を認めたので報告するととすに，ガス発生に関 して考察を加えてみたい。

\section{症例}

患者 : 29歳, 女性.

既往歷：10力月前，巨大児分婏の他は特にない，

現病歴：2〜3 年前からるい瘦が目立ち, 多渴多领で 元気がなく，特に出産後は体の異常感が強く，時折不定 の胃腸障害を訴えていた。来院当日の午後，突然，背 部, 右肩に放散する上腹部痛が出現し，持続性の激痛と なつた．悪心呕吐を綝返えすうち意識混濁をきたし深夜 救急来院した.

現症 : 半昏睡状態で応答なく，疼痛刺激にのみ軽く反 応した。体温 $37^{\circ} 2$ ，血圧90/40，脈拍 120 , 整, 緊張は 不良であつた。呼吸は24で浅く，Kussmaul 大呼吸は認 めない，臭にアセトン臭なく，黄㡺，貧血を認めな い. 皮届は乾燥し, Turgor は低下. 心音, 呼吸音は正 常. 腹部は著しく膨隆し, 肝濁音は消失. 鼓腸著しく, 振水音をわずかに認めた。筇性防禦，Blumberg 徵候は ないが，腸雑音は減弱していた．神経学的に異常なく， 眼底は正常, 鹃液任 $120 \mathrm{mmH}_{2} \mathrm{O}$, 色調は正, カテーテ ル尿は赤褐色でフセトン臭なく，テステーブ法で尿糖 (HH), 尿蛋白 (H), 白血球 6000 .

経過：糖尿性会睡と診断して，直ちにレギュラーイン シュリン 100単位静注, 生食, 乳酸リンゲル $3000 \mathrm{ml}, 5$

$\begin{array}{cccc}\text { 日赤医竂センター第 } 2 \text { 外科 } \\ \text { 板 } & \text { 東 } & \text { 隆 } & \text { 文 } \\ \text { 豊 } & \text { 島 } & \text { 宏 } \\ \text { 太 } & \text { 中 } & \text { 弘 }\end{array}$

\%ブドウ糖 $500 \mathrm{ml}$ の補液療法を行つたところ意識障害 の改善がみられたが，コーヒー残椬の呕吐ととるに再び 昏睡に陥つた．消化管の出血性ショックを否定できず， 輸血 $400 \mathrm{ml}$ を行つたが，9時間後の翌朝，全腹部の筇性 防禦，Blumberg 徽候が影著となり，更に血压の低下を 認めたため，尿一般，血液一般，胸䧗部単純 $\mathbf{X}$ 線，ガス トログラフィンによる胃部透視, ECG のみを施行して 救急手術を行つた。

検查所見：RBC 527万，Hb $18.2 \mathrm{~g} / \mathrm{dl}$, Ht 58\% で蕽 縮著明. WBC 4800, 血糖值は実に 762mg/dlで異常に高 い. 尿糖 $5 \mathrm{~g} / \mathrm{dl}$, アセトン (十), 扁平上皮は数個, ECG は頻脈で全誘導でST の低下を認めた.

胸部 $\mathbf{X}$ 線（図 1 ）：心陰影，肺野に異常なく，左右横 隔膜は挙上しているが，横隔膜下に遊離ガスはない．左 右䅡部軟部組織に預静脈内ガスと思われる索状の淡い数 条の陰影を認める。

腹部単純X線（図 2 ）：䁌より S 字結腸までの全腸管 に intraluminal gas が充満し腸管の扗張がみられるが, 鏡面像はなく，絞拒係稀を思わせる像もない，右下腹部 腸管壁に intramural gas を思わせる蜂窩状陰影がある が, pneumatosis とは断定できない，图3はガストログ

図 1 術前胸部 X 線像

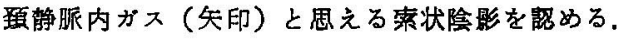

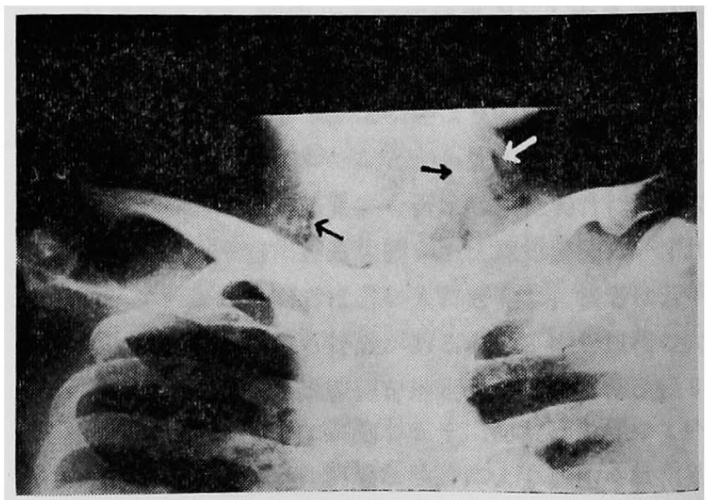


図 2 脜部単純 X線像

胁張胆管に intraluminal gas が充満している。

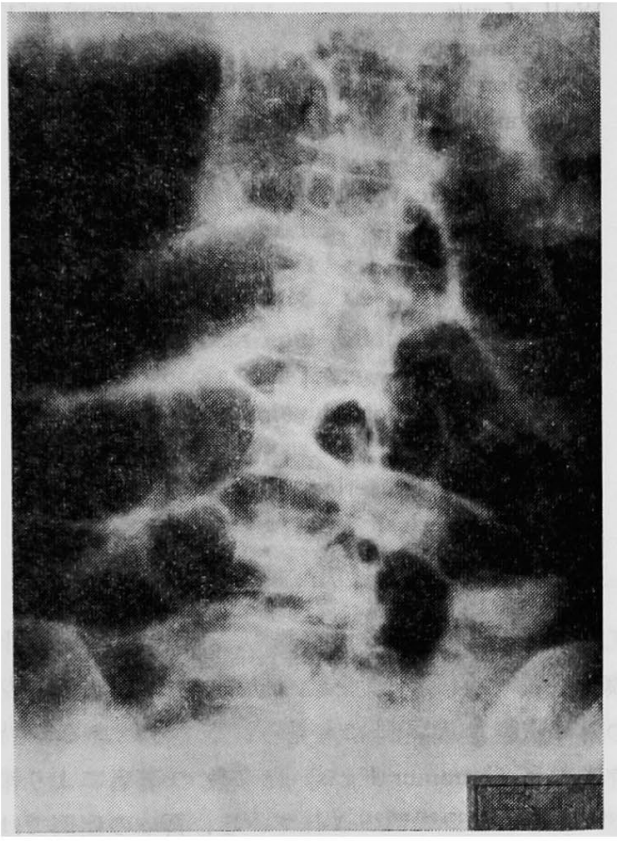

图 3 胃部透視肝門部拡大像 樹枝状陰影は HPVG

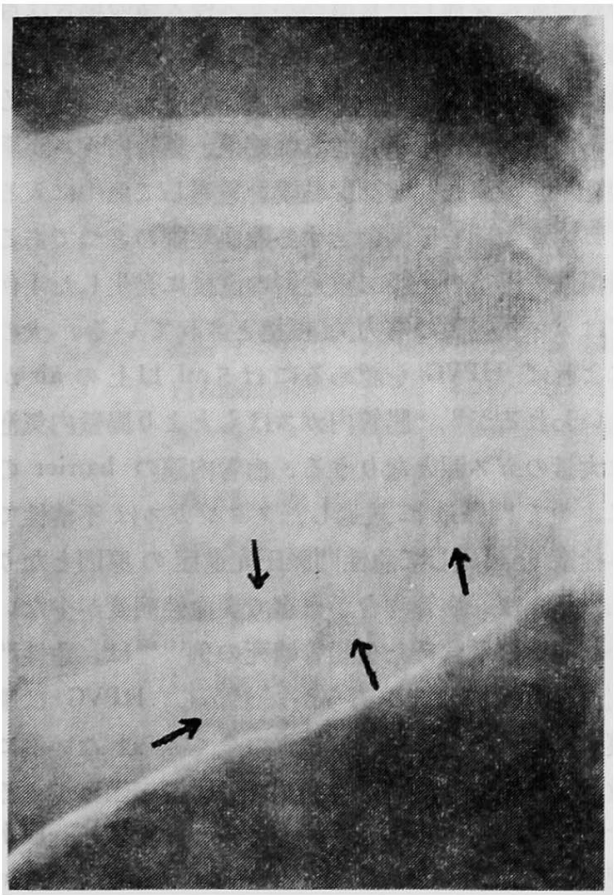

图4 胃体部の術中所見

Vasa gastroepiploica に数珠状の多数の気泡を認 める.

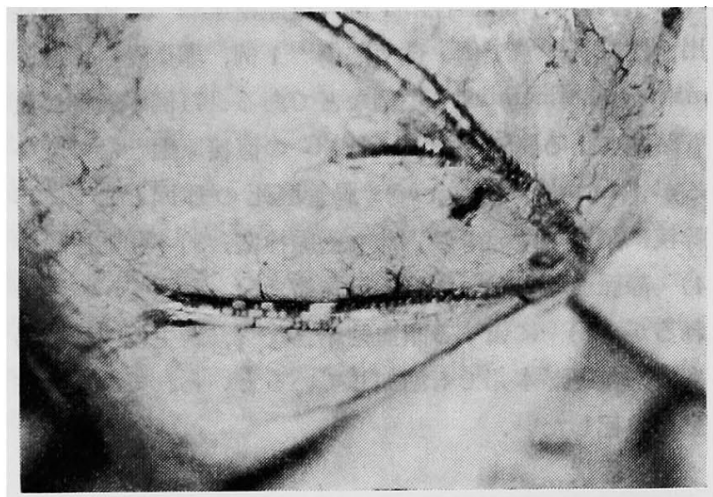

ラフィンによる胃部透視肝門部の拡大写真であるが，肝 門附近より肝辺縁に向う，肺斑理とは明らかに走行の異 なる樹枝状の淡い陰影（矢印）を認め，術後ではあるが HPVG と診断した.

開腹所見 : 大腸菌臭の強い血性黄色の混濁した腹水を 認め，小腸，大腸はとすに極度に膨满している。空腸起 始部より回腸末端, 右半結腸, すなわち上腸管膜動脈領 域の腸管は黑蝎色で半壊死状態で, 斑点状の壊死部およ び益血を認めた。左半結腸は稍々頜血様であるが堎死性 变化はない，最も異常な所見は，胃大網動静脈，大網動 静脈, 中結腸動静脈, 上腸間膜動静脈の各枝の血管壁を 透して見える数珠状の多数の小気泡である（図4）.気泡 は穿刺により airであることを確認した，上腸間膜動脈 根部の搏動は正常であるか，気泡を認める動脈枝には搏 動がなく，気泡は完全に静止している．肝固有動脈の搏 動も弱く，肝の大きさは正常であるが貧血様であつた。

小腸に小開空を置き，1500ml の血性内容を吸引後， 腹䒜内のドレナージのみで創を閉じたが，患者は間もな く死亡した。

\section{考按}

1) 年嘢, 性差

原知患の大部分が新生児壊死性腸炎と成人の腸間膜血

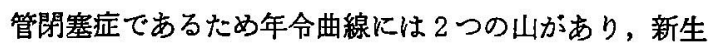
児の平均年令は13日”，成人のそれは63歳である．新生 児では女児が男児の 2 倍であるが，成人では性差を認め ない.

2) 原疾患

文献的に集計した71例の HPVG のちち，壊死性腸炎 1) 3) 6) 5) 6) 31) 32 例，胎児赤芽球症 ${ }^{7} 3$ 例，上腸間膜動脈血 
栓(3) 8) 9) 14) 33) 11 例，同静脈血栓113) 19) 14) 15) 5 例，同動脈 栓塞 ${ }^{2015) 16)} 2$ 例，腹䏶動脈血栓 ${ }^{12} 2$ 例，腹部大動脈血 栓 ${ }^{16)} 1$ 例, 幹門脈血栓 ${ }^{12} 1$ 例, 重症糖疗病早 2 例，急性

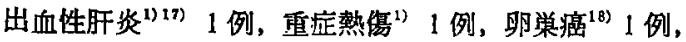

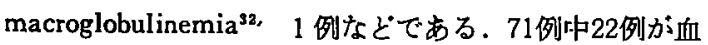
管閉塞による腸管壊死が HPVG の直接原因となててい るが，Ottinger ${ }^{19)}$ によれば腸管壤死の原因として，1） 幹枝に閉塞のないるの，2）動脈栓塞，3）動脈血栓， 4）静脈血栓，5）解嵟性動脈瘤，6）動脈炎が举げら れるが，1）に属する阻血性結腸炎 ${ }^{20)}$, 新生児塤死性晹 炎2) などが本邦です增加しているといわれており, 注 意を喚起したい.

3) 应状

新生児壤死性腸炎は不定の腹部症状を初発とし, 胆汁 性呕吐, 腹部膨満, 血性下㰾が現われ, 高度の脱水状態 に宿り，腸管の冴孔を抗こし易い，病状は殆んど常に進 行性で，績極的な補液，抗生剂の投与にもかかわらず， 数時間から数日以内に死の転掃" 5)631 をとる。

他方, 成人の腸間膜血管閉塞症は abdominal apoplexy と呼ばれるように, 突然の腹痛で始まり，呕吐，下峲， 血便，腹部膨满が出現し與型的な沉発性腹膜资の症状を 呈し，急速にショック状態に陥る，前者は新生児の脱水 状態, 後者は全身の動脈硬化が焦行した高令者で，いず れるショック状態にあるため救急手術を行つてす予後は 極めて悪い。

\section{4) 診断}

HPVG はしばしば一過性帛11)19121)22) であるため数時 間ごとの撮影が必要であり，多量の扗張晹管内ガス，肺 斑理，軟部組織との鑑別が困難ならえ重症例ではポータ ブル撮影で行なわれるため解像力が劣り，乙かも一般に は HPVG に対する認識が少ないため術前診断は極めて 困難である。

典型的な HPVG は，肝門部より肝辺縁に向う樹枝状 の炏い陰影としてとらえられるが，肝内胆管ガスとの鑑 別には，門脈血の流れは centripetal であり胆汁は centrifugal であるため，前者ではガス像が肝辺猭に散在 し，後者では肝門附近に集合することを考虑する，従 つて, 肝辺䋑から $2 \mathrm{~cm}$ 以内の陰影は HPVG と診断して よいといわれる17．しかし，肝内ガス陰影を認める場合 は，胆道内ガスとの鑑別上，内胆计瀋，球後溃晹などを 考虑した検索が必要である゙3.

本症には肝門脈系以外の血管内ガスが併存することが

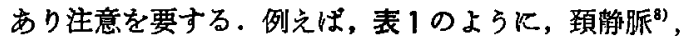

\section{表 1 Gas outside Hepatic Portal Vein}

Wall of guts

Jejunum

Colon

Stomach

Veins

Mesenteric veins 7

Vena cava 3

Hepatic vein

Jugular vein 2

Right atrium 3

Brain 1

All intraperitoneal veins 1

Arteries

Mesenteric arteries 2

Iliac arteries 1

Intercostal arteries

1

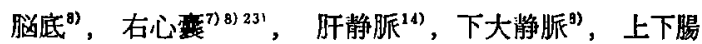

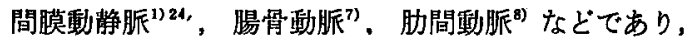
その外に腹脭，縦隔洞にも見られることがある。特化 腸管壁ガス (intramural gas) は多数の著者により報告 1) 3) 5) 6) 73 (3) 137 13) 24) 25) 26) 27) 31)されている．吾々の症例では術 前の胸部X楾で頝静脈ガスを確認した。

5）ガス発生機序

経䏴静脈交換輸血 ${ }^{121)}{ }^{23)}$ あるい:は輸液療法中の発生， 腸管獏静脈に穿通した胃濽㴻がガス侵入路の場合は自明 であるが(10)，他の例ではガス発生機序，侵入路に関乙不 明な点が多く，大別して2つの機序が考えられている。 すなわち，腸管内王が方進した結果，腸管内ガスが腸壁 の壊死栄, 潰痬底, ビラン粘膜を通過して血中に入る説

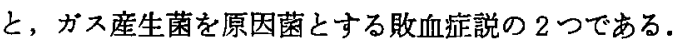
溃湯性大腸炎の注腸二重造影の直後に発生した 1 例 ${ }^{28)}$ などはガス透過説の有力な根拠とされている．犬の実 験によれば HPVG を認めるには $5 \mathrm{ml}$ 以上の air が必 要といわれるがが，腸管内ガスはもとより腸壁内気泡な どは大量のガス源となりらる．血管内膜の barrier の破 䅠によつて門脈系に透過したメタンガスは不溶性で， ガス栓塞を形成して急性門脈圧六進症の原因となりう る $^{3}$ 。例えば，血管吻合が豊富で虚血性病変が少ないと いわれる直腸も含めた全腸管壊死の例 ${ }^{16)}{ }^{27)}$ は，急性門脈 圧六進が原因ではなかろらか。しかし，HPVG は腸管 粘膜正常例，あるいは腸管拡張の全くみられない例にす 多数発生しており，ガス透過説では説明が困難である.

一方，表 2 に示すよらに，HPVG 症の血中，腹水で 同定された細菌のうち，E. coli，Aerobacter aerogenes, 


\section{表 2 Bacterial Analysis in HPVG}

Gas forming species :

E. coli 13

Aerobacter aerogenes

Clostridium welchii

Cl. paraputrificans

Proteus mirabilis

Klebsiella aerobacter

Salmonella group D

Other species :

Staphylococcus epidermidis

Enterococcus

Pseudomonas aeruginosa

Alpha-streptococcus

Negative culture

Culture not performed

total

4

6

1

2

1

1

3

1

1

1

6

27

52

clostridium などのガス産生菌は腸内常在菌であり，腸 間膜動脈閉塞症など abscess under pressure ${ }^{7)}$ の状態にあ ると，細菌は容易に門脈系に透過して敗血症をおこすと 考えられる. 全身の動脈壁に細菌の cluster が証明され た例 ${ }^{3)}$ ，吾々の例のように感染に対し抵抗力の弱い重症 糖疗病に併発した例，さらに肝，門脈，頝静脈，右心衰 内のガス分析により，その組成が細菌産生ガスに類似す ることなどは敗血症説の強い根拠となつている. 最近, 福島ら ${ }^{33)}$ の㬰験によれば air は静脈側からリンバ管のみ に移行し動脈側には決して透過しないと報告している が，自験例および多数の文献上動脈側にもガスが確認さ れておりこのことも敗血症を強く示唆している。
次に, Stevenson ${ }^{5 / 6)}$ は38例の蓴死性腸炎の97\%に pneumatosis を，27\%に HPVGを羿めており，pneumatosis と HPVG は病因論的に密接な関係があると考えられ る. 原発性の pneumatosis は腫煌性の gas cyst と考えら れ消化器症状は軽微であるが29)，内膜細胞に裏らちされ たcyst は腸壁の炎症の結果りンパ管が閉塞されて生ずる と考えられている。しかし，腸壁の壊死組織間隙に散在 する気泡はガス産生の産物であるのか，あるいは既述の 腸内王六進に基ずく機械的ガス透過によるものか定説は ない，壊死性腸炎之腸間膜血管閉塞症に続発する pneumatosis と原発性 pneumatosis との比較を表 3 によぬ る.

\section{6) 治療}

文献上死亡率は $91 \%$ であるが，早期診断に続く積極的 な治療により救命しらる例すあると考える。呕吐，下脷 に上る脱水状態は血液の粘稠度を増大し血栓症を悪化さ せるため大量の輸液を必要とし，広範囲スペクトラム抗 生剤の投与は言らまであない.エンドトキシンショック が筮われる場合は，最近の知見では，ステロイドの大 量投与あるいはトラジロールが奏功するといわれる。が ス発生の敗血症説によれば HPVG は endotoxemia の 1 改候とる考えられるので, 今後臨床的に検討を加えた い。腸管壊死例では早期切除が原則であるが，患者の risk によつては壊死腸管の exteriorization にとどめるこ とも考えられよう．さらに，血栓あるいはガス塞栓によ る急性門脈王亢進症が存在する時には全消化管の壊死の 恐れああり，原因の除去に努めるべきである。

表 3 Pneumatosis cystoides intestinalis

\begin{tabular}{|c|c|c|c|}
\hline & Primary & $\begin{array}{l}\text { Necrotizing } \\
\text { Enterocolitis }\end{array}$ & $\begin{array}{l}\text { Mesenteric } \\
\text { vascular occlusion }\end{array}$ \\
\hline Age & infants \& adults & infants only & adults only \\
\hline Frequency & rare & rare & not so rare \\
\hline Bowel & almost normal & $\begin{array}{l}\text { gangrenous or ulc- } \\
\text { erative }\end{array}$ & gangrenous \\
\hline Diarrhea \& melena & none & present & present \\
\hline Gas cyst & $\begin{array}{l}\text { prominent in subs- } \\
\text { erosa }\end{array}$ & submucosa & subserosa \\
\hline Site & $\begin{array}{l}\text { ileum-end, colon, } \\
\text { vagina, bladder }\end{array}$ & $\begin{array}{l}\text { ileum-end, caecum, } \\
\text { colon }\end{array}$ & all guts \\
\hline Lining cells & endothelium? & necrotic tissue & necrotic tissue \\
\hline Pneumo-peritoneum & rare & often & often \\
\hline Vascular occlusion & none & none & present \\
\hline HPVG & rare & often & rare \\
\hline Prognosis & good & very poor & very poor \\
\hline
\end{tabular}




\section{おわりに}

HPVG は耳慣れ嫹葉であり，その知識が無ければ 存在診断は不可能である. HPVG は致命的な徵候であ ることを念頭に，外科医の監視下で積極的な治療を試み なければならない，文献上71例の集計に自験例 1 例を追 加して検討を加えた.

(本論文の要旨江第 673回外科集談会に於てH P V G の本邦第 1 例として報告した）

\section{文献}

1) Fred, H.L. et al.: Am. J. Med., 44: 557, 1968.

2) Touloukian, R.J. et al.: J. Pediat. Surg., 2: 389, 1968.

3) Susman, N. \& Senturia, H.L.: Am. J. Roent., 83: 847, 1960.

4) Berdon, W.E. et al.: Radiology., 83: 839, 1964.

5) Stevenson, J.K. et al.: Am. J. Surg., 118: 260, 1969.

6) Stevenson, J.K. et al.: J. Pediadt. Surg., 6: 28, 1971.

7) Wolfe, J.N. \& Evans, W.A.: Am. J. Roent., 74: 486, 1955.

8) Wiot, J.F. \& Felson, B.: Am. J. Roent., 86: 920, 1961.

9) Guyer, P.B. \& Grainger, K.: Brit. J. Radiol., 36: 379, 1963.

10) Rigler, L.G. \& Pogue, W.L.: Am. J. Roent., 94: 240, 1965.

11) Goldstein, W.B. et al.: Am. J. Roent., 97: 220, 1966.

12) Sheiner, N.M. et al.: Canada M.A.J., 95: $611,1966$.
13) McCandless, R.G.: Am. J. Roent., 92: 1162, 1964.

14) Pagan-Carolo, J. \& DeMovy, E.H.: Am. J. Roent., 91 : 699, 1964.

15) Stewart, J.O.R.: Brit. Med. J., 1: 1328, 1963.

16) Barrett, A.F.: Clin. Radiol., 13: 92, 1962.

17) Sisk, P.B.: Radillory., 77: 103, 1961.

18) Dardik, H. et al.: Am. J. Gastroenterol., 55: 273, 1971.

19) Ottinger, L.W. \& Austen, W.G.: S.G.O., 124: 251, 1967.

20）豊島 宏伍か：臨床外，27：569，1972.

21) Schmidt, A.G.: Radiology., 88: 293, 1967.

22) Paciulli, J. \& Jacobson, G.: Am. J. Roent., 99: 629, 1967.

23) Frates, R.E.: Radiology., 85: 879, 1965.

24) Fink, D.W. \& Boyden, E.M.: Radioogy., 87: 341, 1966.

25) Schorr, S.: Radiology., 81: 285, 1963.

26) Musa, D.W.: Ann. I-t. Med., 63: 783, 1965.

27) Sachs, D. \& Pogue, W.L.: Am. J. Roent., 111: 269, 1966.

28) Lazer, H.P.: Am. J. Dig. Dis., 10: 259, 1965.

29) Bockus, H.L.: Gastroenterology vol. 2, p. 219, Saunders, Phil. 1969.

30) 山本正生泟か：小児科, $12: 1167,1971$.

31）矢野博道：医事新報，2526：9，1972.

32) Edwards, A.M. et al.: Canada M.A.J., 91: 1300, 1964.

33) 福島恒男泀加:臨外, $29: 1123,1975$. 